\title{
Study of $\mathrm{ZnAl}_{2} \mathrm{O}_{4}$ spinel nanoparticles synthesized using gelatin as organic precursor
}

\section{(Estudo de nanopartículas do espinélio $\mathrm{ZnAl}_{2} \mathrm{O}_{4}$ sintetizadas utilizando gelatina como precursor orgânico)}

\author{
H. P. Macedo $^{1 *}$, R. L. B. A. Medeiros ${ }^{1}$, R. A. B. Nascimento ${ }^{1}$, A. A. S. Oliveira ${ }^{2}$, \\ G. P. Figueredo ${ }^{3}$ R. M. Braga ${ }^{4}$ D. M. A. Melo ${ }^{1,5}$ \\ ${ }^{1}$ Federal University of Rio Grande do Norte, Graduating Program in Materials Science and Engineering, \\ 59078-970, Natal, RN, Brazil \\ ${ }^{2}$ Federal University of Rio Grande do Norte, Graduating Program in Petroleum Engineering, Natal, RN, Brazil \\ ${ }^{3}$ Federal Institute of Education, Science and Technology of Maranhão, Chemistry Department, São Luis, MA, Brazil \\ ${ }^{4}$ Federal University of Rio Grande do Norte, Escola Agrícola de Jundiai, Macaiba, RN, Brazil \\ ${ }^{5}$ Federal University of Rio Grande do Norte, Graduating Program in Chemistry, Natal, RN, Brazil
}

\begin{abstract}
In this work, zinc aluminate spinel powders were prepared by a fast, simple, eco-friendly and low-cost modified Pechini method using commercial gelatin as the organic precursor. The materials were calcinated at 600,700 and $800{ }^{\circ} \mathrm{C}$ and characterized by thermogravimetric analysis, in situ and ex situ X-ray diffraction (XRD), $\mathrm{N}_{2}$-adsorption/desorption isotherms and scanning electron microscopy. The results showed that single phase $\mathrm{ZnAl}_{2} \mathrm{O}_{4}$ particles with spinel structure were successfully obtained resulting in a high purity, nanometric, homogeneous and mesoporous materials. The in situ XRD results showed that the crystalline spinel structure of $\mathrm{ZnAl}_{2} \mathrm{O}_{4}$ started forming at a temperature lower than $600{ }^{\circ} \mathrm{C}$, revealing powders with crystallite size smaller than 40 $\mathrm{nm}$, which increased with increasing the temperature ( $91 \%$ of increase between 600 and $800{ }^{\circ} \mathrm{C}$ ). The effect of calcination time showed that the materials calcinated at $600{ }^{\circ} \mathrm{C}$ for $3 \mathrm{~h}$ presented the higher percentage of crystallite growth due to the increase of crystallinity. The $\mathrm{ZnAl}_{2} \mathrm{O}_{4}$ samples retained their pore size up to $700{ }^{\circ} \mathrm{C}$.
\end{abstract}

Keywords: zinc aluminate, gelatin, in situ XRD, spinel, nanoparticles.

\section{Resumo}

Neste trabalho, pós do espinélio aluminato de zinco foram preparados por um método Pechini modificado, rápido, simples, ambientamento seguro e de baixo custo, utilizando gelatina comercial como precursor orgânico. Os materiais foram calcinados a 600, 700 e $800{ }^{\circ} \mathrm{C}$ e caracterizados por análise termogravimétrica, difratometria de raios $X(D R X)$ in situ e ex situ, isotermas de adsorção/dessorção de $\mathrm{N}_{2}$ e microscopia eletrônica de varredura. Os resultados mostraram que as partículas de $\mathrm{ZnAl}_{2} \mathrm{O}_{4}$ monofásicas com estrutura espinélio foram obtidas com sucesso resultando em materiais de alta pureza, nanométricos, homogêneos e mesoporosos. Os resultados de DRX in situ mostraram que a estrutura cristalina do espinélio $\mathrm{ZnAl}_{2} \mathrm{O}_{4}$ começou a se formar em temperaturas inferiores a $600{ }^{\circ} \mathrm{C}$, revelando pós com tamanho de cristalito menor que $40 \mathrm{~nm}$, que cresceram com o aumento da temperatura $\left(91 \%\right.$ de aumento entre 600 e $\left.800{ }^{\circ} \mathrm{C}\right)$. O efeito do tempo de calcinação mostrou que os materiais calcinados a $600{ }^{\circ} \mathrm{C}$ por 3 h apresentaram maior porcentagem do crescimento do cristalito devido ao aumento da cristalinidade. As amostras de $\mathrm{ZnAl}_{2} \mathrm{O}_{4}$ mantiveram o tamanho dos poros até $700{ }^{\circ} \mathrm{C}$.

Palavras-chave: aluminato de zinco, gelatina, DRX in situ, espinélio, nanopartículas.

\section{INTRODUCTION}

Zinc aluminate $\left(\mathrm{ZnAl}_{2} \mathrm{O}_{4}\right)$ is a ternary oxide with spinel structure that combines desirable properties such as high mechanical strength, high thermal and chemical stability, low sintering temperature and excellent optical properties [1-3]. Therefore, it is currently being used as hightemperature material, optical and luminescent materials [4], pigments [5], catalysts [6], photocatalysts [7], sensors [8] and catalyst support [9]. Many chemical methods have been

* (D) https://orcid.org/0000-0002-2072-3105 used for the synthesis of $\mathrm{ZnAl}_{2} \mathrm{O}_{4}$ which includes solid-state route [10], metal-chitosan complexation method [11], coprecipitation [8], modified citrate sol-gel [12], combustion [13], microwave combustion [14], hydrothermal [15, 16], sol-gel $[17,18]$ and polymeric precursor [19].

In this paper, we report the synthesis of nanocrystalline $\mathrm{ZnAl}_{2} \mathrm{O}_{4}$ powders by a modified Pechini method using commercial gelatin as an organic precursor. Due to its solubility in water and its ability to associate with metal ions in solution (through the amino and carboxylic groups present in its structure), gelatin can be used as a binder gel to form a metal-chelate complex system. Thus, oxide nanoparticles 
can be obtained at relatively lower temperatures than the other preparation methods [20]. The process is an alternative simple, low-cost and environmentally friend method, which produces nano-sized powders with high purity, homogeneity and good control of stoichiometry. Recent studies have used gelatin as a polymerization agent to produce mixed oxides with spinel [21-23] and perovskite [24-26] structures. Thus, the aim of this work was to synthesize zinc aluminate nanoparticles using gelatin as an organic precursor and to evaluate the effect of different temperatures of calcination on the structural, morphological and textural properties of the materials.

\section{MATERIALS AND METHODS}

$\mathrm{Al}\left(\mathrm{NO}_{3}\right)_{3} \cdot 9 \mathrm{H}_{2} \mathrm{O}$ (Sigma-Aldrich) and $\mathrm{Zn}\left(\mathrm{NO}_{3}\right)_{2} \cdot 6 \mathrm{H}_{2} \mathrm{O}$ (Sigma-Aldrich) were used as starting materials and commercial flavorless gelatin (Farmafórmula, Brazil) as an organic precursor. First, gelatin was dissolved in deionized water at $50{ }^{\circ} \mathrm{C}$ under constant stirring to obtain a homogeneous solution. Then, suitable amounts of $\mathrm{Zn}\left(\mathrm{NO}_{3}\right)_{2} \cdot 6 \mathrm{H}_{2} \mathrm{O}$ and $\mathrm{Al}\left(\mathrm{NO}_{3}\right)_{3} \cdot 9 \mathrm{H}_{2} \mathrm{O}$ were added separately to the solution. The mixture was kept under stirring at $80^{\circ} \mathrm{C}$ until the formation of a gel, which was pretreated in a muffle furnace at $300{ }^{\circ} \mathrm{C}$ for $3 \mathrm{~h}$ with a heating rate of $10{ }^{\circ} \mathrm{C} \cdot \mathrm{min}^{-1}$ to obtain the precursor material for the desired oxide. A sample of the precursor was submitted to thermogravimetric analysis previously to the calcination. Finally, the precursor powder was calcinated in air atmosphere at 600,700 and $800{ }^{\circ} \mathrm{C}$ for $3 \mathrm{~h}$ with a heating rate of $10^{\circ} \mathrm{C} \cdot \mathrm{min}^{-1}$.

The thermogravimetric analysis of the precursor powder was carried out in an SDT-Q600 thermal analysis system from TA Instruments up to $900{ }^{\circ} \mathrm{C}$ with a heating rate of $\quad 20{ }^{\circ} \mathrm{C} \cdot \mathrm{min}^{-1}$ and a flow rate of $100 \mathrm{~mL} \cdot \mathrm{min}^{-1}$ of air $(99.999 \%)$. The in situ XRD evaluated the formation of $\mathrm{ZnAl}_{2} \mathrm{O}_{4}$ structure based on the evolution of crystallinity and crystallite size during calcination under an oxidizing atmosphere. The measurement was performed in the XPD$10 \mathrm{~B}$ beamline of the Brazilian Synchrotron Light Laboratory $\left(1.7712 \AA\right.$ and $7 \mathrm{keV}$, heating up to $800{ }^{\circ} \mathrm{C}$ at $10{ }^{\circ} \mathrm{C} \cdot \mathrm{min}^{-1}$, under an atmosphere of $21 \mathrm{vol} \%$ of $\mathrm{O}_{2}$ in $\mathrm{N}_{2}$ ). The precursor powder was placed in a furnace installed in a goniometer (Hubber) operating in Bragg-Brentano geometry $(\theta-2 \theta)$ and equipped with the Mythen-1 K detector (Detris) located at a meter of the oven. Scans were performed in the $2 \theta$ range from $30^{\circ}$ to $65^{\circ}$ to verify the formation of the $\mathrm{ZnAl}_{2} \mathrm{O}_{4}$ main peaks. The crystallite size and crystallinity were calculated based on the main peak (311) for each calcination temperature. The ex situ XRD patterns were determined in a Shimadzu XRD 7000 apparatus $\left(\mathrm{CuK} \alpha\right.$ radiation, $2 \theta$ from $20^{\circ}$ to $80^{\circ}$, steps of $0.02^{\circ}$ and counting time per step of $2^{\circ} \cdot \mathrm{min}^{-1}$ ). The Rietveld refinement was performed using the MAUD program v.2.7 to obtain the lattice parameter and crystallite size. The crystallinity was calculated using the XRD-7000 Shimadzu software. The morphological characteristics of the powders were analyzed in a Shimadzu SSX550 scanning electron microscope, operating at $15 \mathrm{kV}$ and equipped with a tungsten filament. The textural characteristics of the samples were determined in a Quanta Chrome NOVA 2000 apparatus based on BET and BJH methods.

\section{RESULTS AND DISCUSSION}

The result of thermogravimetric analysis of the precursor powder thermally treated at $300{ }^{\circ} \mathrm{C}$ for $3 \mathrm{~h}$ is shown in Fig. 1. The decomposition occurred in three distinct steps: i) 30 $300{ }^{\circ} \mathrm{C}$; ii) $300-680{ }^{\circ} \mathrm{C}$; and iii) $680-720^{\circ} \mathrm{C}$. The first stage of weight-loss was associated with the water loss, while the second one was attributed to the elimination of amino acid fragments, usually proline [21]. The last step corresponded to the degradation of glycine [24] and metal nitrates, while above $600{ }^{\circ} \mathrm{C}$ no weight-loss occurred. This behavior was due to the interaction of glycine through carboxyl groups and amine with metallic ions, which provided more stability to the structure [25].

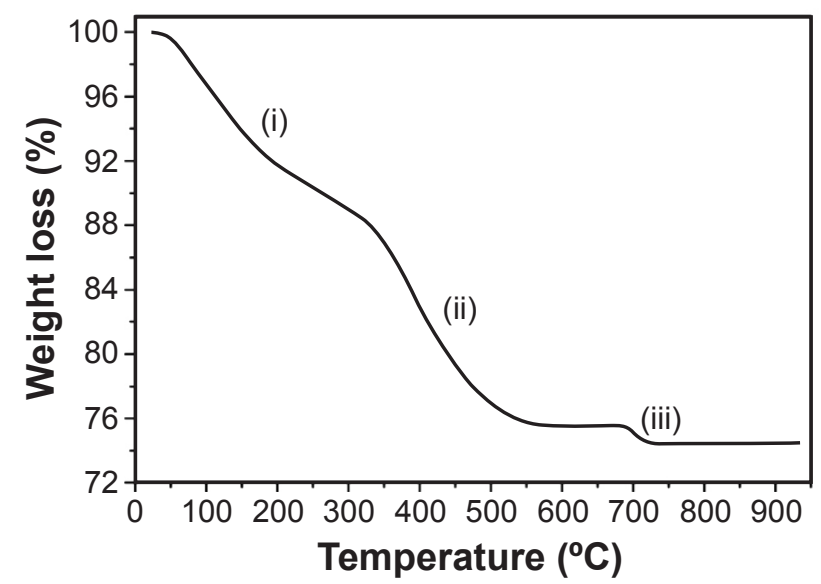

Figure 1: Thermogravimetric curve of the precursor powder heated at $300{ }^{\circ} \mathrm{C}$ for $3 \mathrm{~h}$.

[Figura 1: Curva termogravimétrica do pó precursor précalcinado a $300{ }^{\circ} \mathrm{C}$ por $\left.3 \mathrm{~h}.\right]$

Fig. 2 shows the in situ XRD patterns obtained by simulating the calcination treatment of the precursor powder. It is clearly shown in Fig. 2a that the formation of the crystalline phase of $\mathrm{ZnAl}_{2} \mathrm{O}_{4}$ began at temperatures close to $600{ }^{\circ} \mathrm{C}$, where it is possible to identify the diffraction lines related to the planes (220), (331), (400) and (331). Below $600{ }^{\circ} \mathrm{C}$, it was only possible to identify the diffraction lines related to the planes (220) and (331), showing therefore a predominantly amorphous structure. On the other hand, the diffractograms above $600{ }^{\circ} \mathrm{C}$ showed that the increase in temperature promoted the formation of more intense and well-defined peaks. Vanderlaag et al. [10] also reported the use of gelatin as an organic precursor for the synthesis of $\mathrm{ZnAl}_{2} \mathrm{O}_{4}$, however, they only obtained the structure after high temperature $\left(1000{ }^{\circ} \mathrm{C}\right)$ and long time ( $12 \mathrm{~h}$ ) of calcination. Fig. $2 \mathrm{~b}$ shows the crystallite size and the crystallinity as a function of temperature. Up to $600{ }^{\circ} \mathrm{C}$, the crystallite size remained practically constant $(20 \mathrm{~nm})$, while the crystallinity varied between 0 and $5 \%$. From $600{ }^{\circ} \mathrm{C}$, a sudden increase occurred in both crystallite size and crystallinity as a function of the spinel crystalline 
phase formation of $\mathrm{ZnAl}_{2} \mathrm{O}_{4}$. Comparing the crystallite sizes between 600 and $800{ }^{\circ} \mathrm{C}$, an increase of $91 \%$ was observed. In addition to the effect of temperature, the calcination time was another variable analyzed and the results showed that it is also a crucial factor in the formation and structural characteristics of $\mathrm{ZnAl}_{2} \mathrm{O}_{4}$ and its possible applications, especially at high temperatures.

The ex situ XRD patterns of the samples calcined at 600, 700 and $800{ }^{\circ} \mathrm{C}$ for $3 \mathrm{~h}$ are shown in Fig. 3. All materials showed characteristic diffraction peaks, which can be indexed to (220), (311), (222), (400), (331), (422), (511),
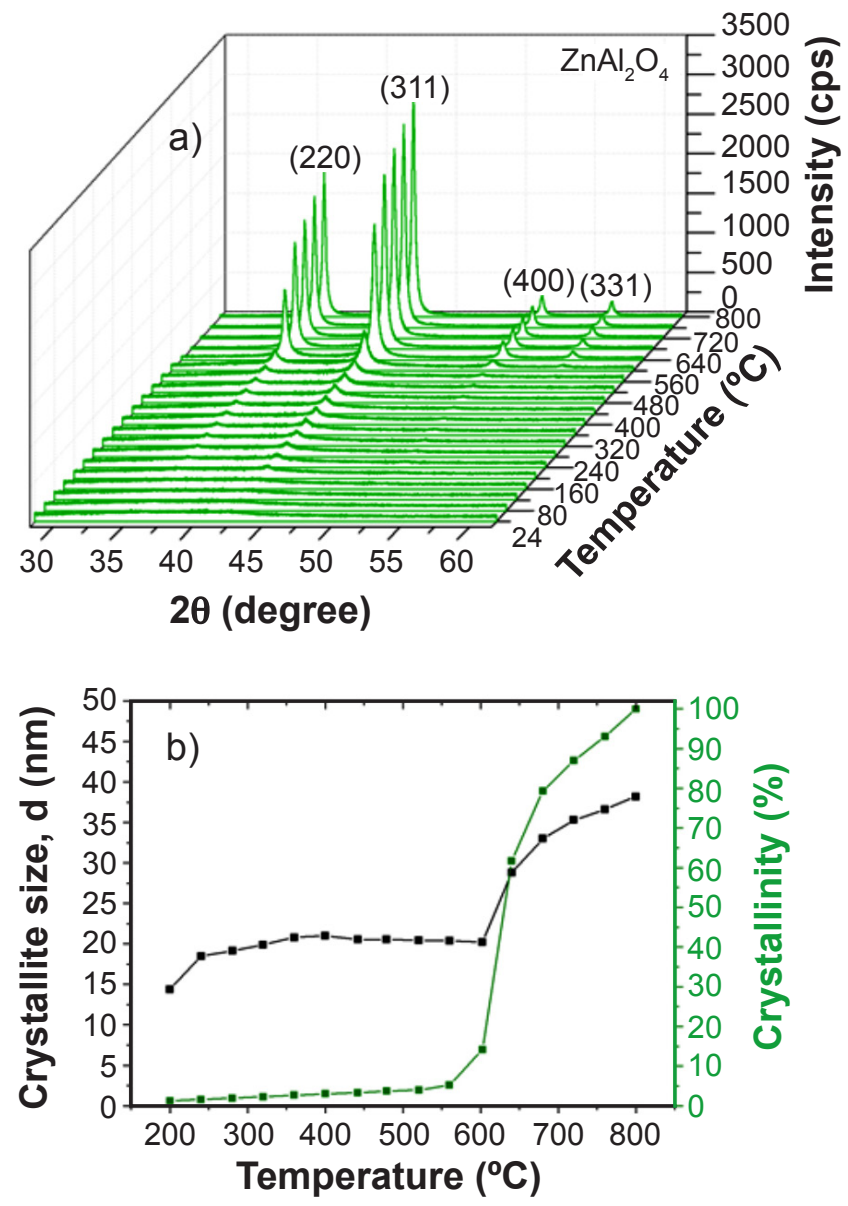

Figure 2: In situ XRD patterns during the calcination (a) and effect of temperature on the crystallite size and crystallinity (b).

[Figura 2: Difratogramas de raios $X$ in situ durante a calcinação (a) e efeito da temperatura no tamanho de cristalito e cristalinidade (b).]
(440), (620) and (533) crystallographic reflections of cubic $\mathrm{ZnAl}_{2} \mathrm{O}_{4}$ spinel structure with Fd-3m symmetry (JCPDS 741138). No diffraction peaks related to secondary phases or impurity were detected, confirming that all materials were single-phase $\left(\mathrm{ZnAl}_{2} \mathrm{O}_{4}\right.$ spinel), revealing the efficiency of using commercial gelatin as an organic precursor to obtain pure oxides. The XRD patterns showed narrow reflections indicating a crystalline material. With increasing the temperature, the intensity of the peaks increased and the width became narrower, which was associated with an increase in the crystallite size $[27,28]$. Table I presents the crystallite size at the beginning and at the end of the $3 \mathrm{~h}$ calcination treatment, where it is observed a remarkable increase in crystallite size at all temperatures, naturally associated with the phenomena of atomic diffusion and formation of the crystalline phase in this range of temperature. The largest increase in crystallite size was observed for the sample calcined at $600{ }^{\circ} \mathrm{C}$, which may be related to the considerable increase in crystallinity, since in situ XRD results indicated a predominantly amorphous structure at the beginning of the treatment at $600{ }^{\circ} \mathrm{C}(<10 \%$ crystallinity). On the other hand, the samples calcined at 700 and $800{ }^{\circ} \mathrm{C}$ showed an increase of $30.7 \%$ and $42.9 \%$, respectively, due to their higher crystallinity $(>85 \%)$ at the beginning of the calcination isotherm when compared to the sample calcined at $600{ }^{\circ} \mathrm{C}$. However, the final crystallite size

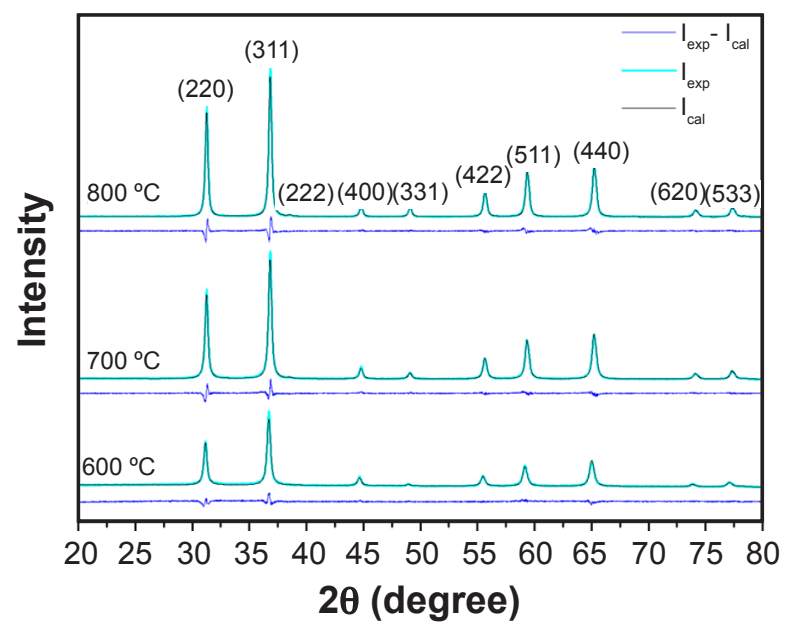

Figure 3: Ex-situ XRD patterns of $\mathrm{ZnAl}_{2} \mathrm{O}_{4}$ calcinated at 600,700 and $800{ }^{\circ} \mathrm{C}$ for $3 \mathrm{~h}$.

[Figura 3: Difratogramas de raios $\mathrm{X}$ ex-situ do $\mathrm{ZnAl}_{2} \mathrm{O}_{4}$ calcinado a 600,700 e $800^{\circ} \mathrm{C}$ por 3 h.]

Table I - Structural and textural data of $\mathrm{ZnAl}_{2} \mathrm{O}_{4}$ powders.

[Tabela I - Dados estruturais e texturais dos pós do $\mathrm{ZnAl}_{2} \mathrm{O}_{4}$.]

\begin{tabular}{cccccccccc}
\hline Sample & $\begin{array}{c}\mathrm{d}_{\mathrm{i}}^{\mathrm{a}} \\
(\mathrm{nm})\end{array}$ & $\begin{array}{c}\mathrm{d}_{\mathrm{f}}^{\mathrm{b}} \\
(\mathrm{nm})\end{array}$ & $\begin{array}{c}\text { Difference } \\
(\%)\end{array}$ & $\begin{array}{c}\mathrm{a}=\mathrm{b}=\mathrm{c}^{\mathrm{d}} \\
(\AA)\end{array}$ & Sig $^{\mathrm{e}}$ & $\mathrm{Rw}^{\mathrm{e}}$ & $\begin{array}{c}\mathrm{SSA}^{\mathrm{f}} \\
\left(\mathrm{m}^{2} \cdot \mathrm{g}^{-1}\right)\end{array}$ & $\begin{array}{c}\text { Pore size } \\
(\mathrm{nm})\end{array}$ & $\begin{array}{c}\mathrm{TPV}^{\mathrm{g}} \\
\left(\mathrm{cm}^{3} \cdot \mathrm{g}^{-1}\right)\end{array}$ \\
\hline $\mathrm{ZnAl}_{2} \mathrm{O}_{4}\left(600^{\circ} \mathrm{C}\right)$ & 19.7 & 37.2 & +88.8 & 8.1097 & 1.54 & 12.61 & 55.3 & 3.57 & 0.053 \\
$\mathrm{ZnAl}_{2} \mathrm{O}_{4}\left(700^{\circ} \mathrm{C}\right)$ & 34.2 & 44.7 & +30.7 & 8.0863 & 1.41 & 11.69 & 37.3 & 3.58 & 0.070 \\
$\mathrm{ZnAl}_{2} \mathrm{O}_{4}\left(800^{\circ} \mathrm{C}\right)$ & 38.2 & 54.6 & +42.9 & 8.0843 & 1.49 & 12.34 & 23.8 & 12.25 & 0.065 \\
\hline
\end{tabular}

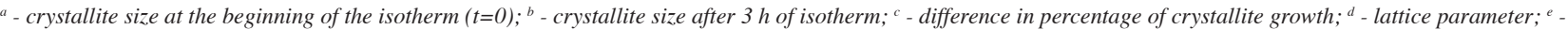
refinement parameter; ${ }^{f}$ - specific surface area ${ }^{g}$ - total pore volume. 

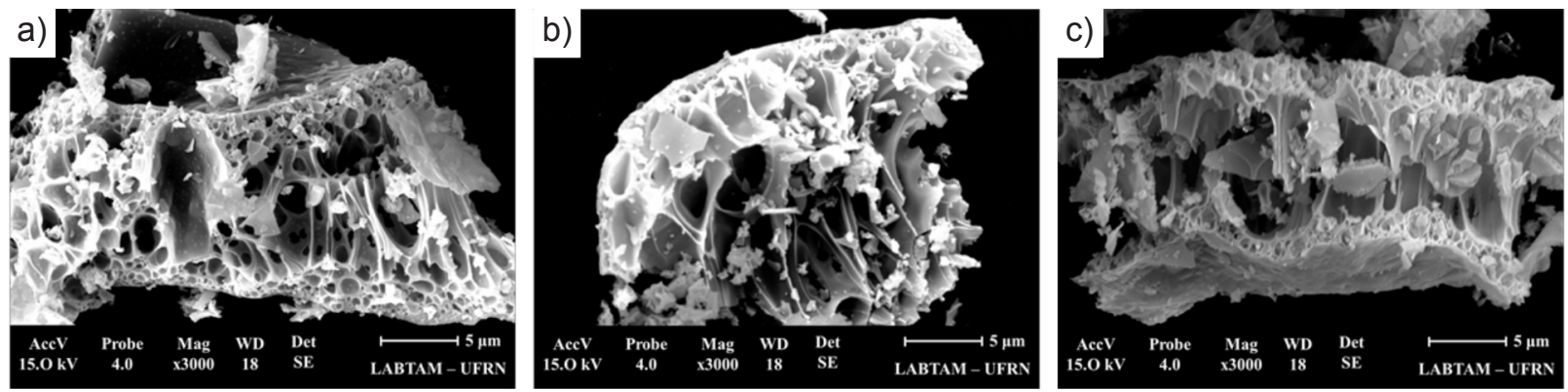

Figure 4: SEM images of $\mathrm{ZnAl}_{2} \mathrm{O}_{4}$ powders calcinated at $600{ }^{\circ} \mathrm{C}(\mathrm{a}), 700{ }^{\circ} \mathrm{C}$ (b) and $800{ }^{\circ} \mathrm{C}$ (c) for $3 \mathrm{~h}$.

[Figura 4: Micrografias dos pós do $\mathrm{ZnAl}_{2} \mathrm{O}_{4}$ calcinados em $600{ }^{\circ} \mathrm{C}\left(\right.$ a), $700{ }^{\circ} \mathrm{C}$ (b) e $800{ }^{\circ} \mathrm{C}$ (c) por $3 \mathrm{~h}$.]

also increased as a function of temperature. Therefore, for applications over long periods of time at high temperatures, it is important to adjust the calcination time to stabilize the crystallite size. The lattice parameters (Table I) of 8.1097, 8.0863 and $8.0843 \AA$ for $\mathrm{ZnAl}_{2} \mathrm{O}_{4}$ samples calcinated at 600 , 700 and $800^{\circ} \mathrm{C}$, respectively, were very close to the theoretical value of gahnite (8.0990 $⿱$ ) mentioned in the JCPDS 74-1138 file. The values of Sig and Rw parameters obtained from Rietveld refinement can also be seen in Table I. To obtain a good refinement these values should be in the range of 1 and 2 and 10 and 20, respectively [29].

SEM images of the powders calcinated at different temperatures are shown in Fig. 4. As can be observed, the temperature did not significantly influence the final morphology of the powders. The micrographs revealed powders with plate-like aggregates with irregular and porous structures. This morphology is typical of powders synthesized using gelatin as a precursor, resulting from the intense release of gases associated with the decomposition of gelatin during the heating process $[21,22,24,25]$.

Fig. 5 shows the nitrogen adsorption-desorption isotherms (Fig. 5a) and the corresponding pore size distribution (Fig. 5b) of the $\mathrm{ZnAl}_{2} \mathrm{O}_{4}$ powders calcinated at different temperatures. According to IUPAC classification [30], all the samples had a type IV isotherm and H2 hysteresis, which indicated the presence of mesoporosity. The mesoporous structure was confirmed by the analysis of pore size distribution (Fig. 5b), which displayed a unimodal distribution with an average pore size of approximately $3.57,3.58$ and $12.25 \mathrm{~nm}$ (Table I) for samples calcinated at 600,700 and $800{ }^{\circ} \mathrm{C}$, respectively, that can be attributed to interparticle void porosity [31]. It can be observed that up to $700{ }^{\circ} \mathrm{C}$ the $\mathrm{ZnAl}_{2} \mathrm{O}_{4}$ samples retained their pore size. The maximum and width of pore size distribution increased with calcination temperature. In addition, the pore size, as well as the total pore volume, increased with the temperature. The surface area was measured via the $\mathrm{N}_{2}$ adsorption-desorption technique calculated by the BET method. The samples calcinated at 600,700 and $800{ }^{\circ} \mathrm{C}$ displayed specific surface areas of 55.3, 37.3 and $23.8 \mathrm{~m}^{2} . \mathrm{g}^{-1}$, respectively (Table I). The surface areas gradually decreased with increasing calcination temperature suggesting that sintering occurred during the calcination process corresponding to the increase of crystallite size. a)

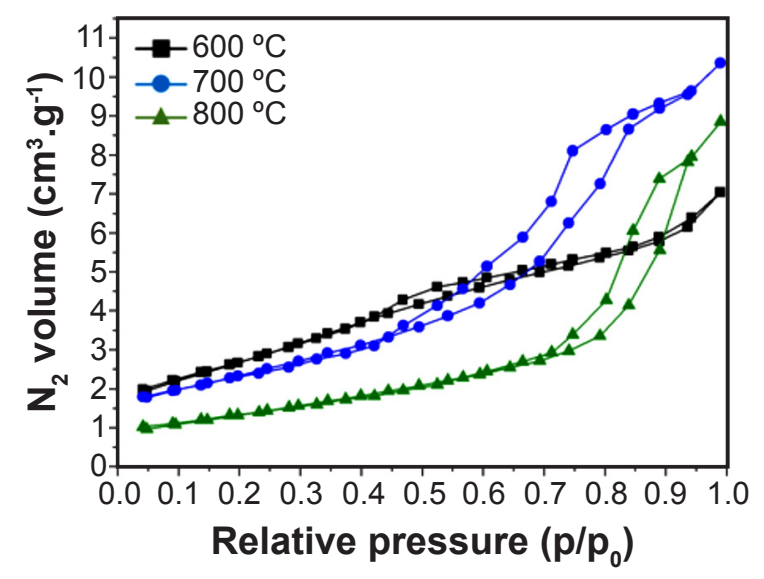

b)

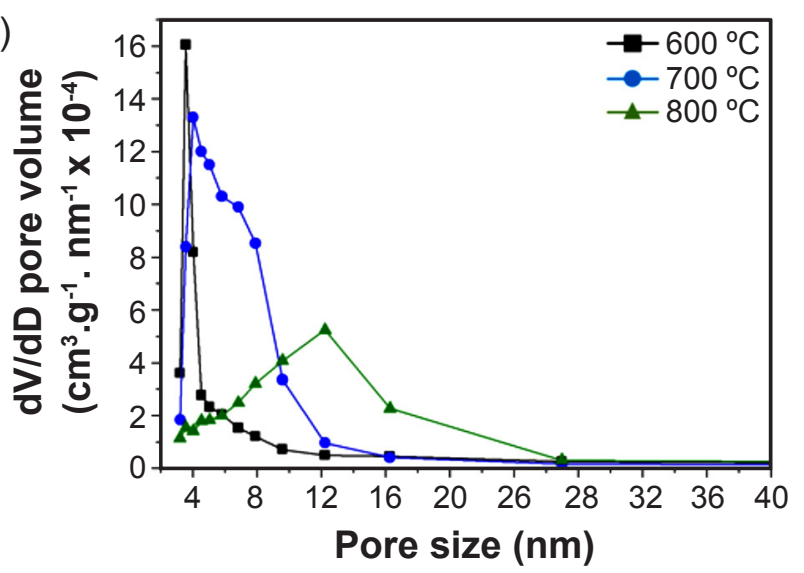

Figure 5: $\mathrm{N}_{2}$ adsorption/desorption isotherms (a) and pore size distribution (b) of $\mathrm{ZnAl}_{2} \mathrm{O}_{4}$ powders calcinated at 600, 700 and $800{ }^{\circ} \mathrm{C}$ for $3 \mathrm{~h}$.

[Figura 5: Isotermas de adsorção/dessorção de $N_{2}$ (a) e distribuição de tamanho de poros (b) dos pós de $\mathrm{ZnAl}_{2} \mathrm{O}_{4}$ calcinados a 600, 700 e $800{ }^{\circ} \mathrm{C}$ por $3 \mathrm{~h}$.]

\section{CONCLUSIONS}

Single phase zinc aluminate nanoparticles with spinel structure were successfully obtained at temperatures lower than $600{ }^{\circ} \mathrm{C}$ by a fast, simple, non-toxic and low-cost route using commercial gelatin as an organic precursor, making it a promising alternative route to the usual synthesis methods. The method described in this work led to the obtainment of high purity, nanometric, homogeneous and mesoporous 
materials, which are important features for technological applications. The synthesized $\mathrm{ZnAl}_{2} \mathrm{O}_{4}$ powders exhibited an increase in the crystallite size with increasing time and temperature of calcination. The effect of calcination time showed that the materials calcinated at $600{ }^{\circ} \mathrm{C}$ for 3 $\mathrm{h}$ presented the highest percentage of crystallite growth $(\sim 88 \%)$ due to the increase of crystallinity. The $\mathrm{ZnAl}_{2} \mathrm{O}_{4}$ samples retained their pore size up to $700{ }^{\circ} \mathrm{C}$, and the specific surface area decreased with increasing the temperature. The morphology was not significantly influenced by the temperature, presenting plate-like aggregates with irregular and porous structures.

\section{ACKNOWLEDGMENTS}

The authors wish to thank Brazilian agencies Coordenação de Aperfeiçoamento de Pessoal de Nível Superior (CAPES) and Conselho de Desenvolvimento Científico e Tecnológico $(\mathrm{CNPq})$ for financial support and the Brazilian Synchrotron Light Laboratory (LNLS) for in situ XRD analysis.

\section{REFERENCES}

[1] D.-L. Ge, Y.-J. Fan, C.-L. Qi, Z.-X. Sun, J. Mater. Chem. A 1, 5 (2013) 1651.

[2] X. Tian, L. Wan, K. Pan, C. Tian, H. Fu, K. Shi, J. Alloys Compd. 488, 1 (2009) 320.

[3] R. Ianoş, S. Borcănescu, R. Lazău, Chem. Eng. J. 240 (2014) 260.

[4] S.V. Motloung, F.B. Dejene, H.C. Swart, O.M. Ntwaeaborwa, J. Lumin. 163 (2015) 8.

[5] R. Yang, A. Han, M. Ye, X. Chen, L. Yuan, J. Alloys Compd. 696 (2017) 1329.

[6] C.T. Alves, A. Oliveira, S.A.V. Carneiro, A.G. Silva, H.M.C. Andrade, S.A.B. Vieira de Melo, E.A. Torres, Fuel Process. Technol. 106 (2013) 102.

[7] C.G. Anchieta, D. Sallet, E.L. Foletto, S.S. da Silva, O. Chiavone-Filho, C.A.O. do Nascimento, Ceram. Int. 40, 3 (2014) 4173.

[8] B. Cheng, Z. Ouyang, B. Tian, Y. Xiao, S. Lei, Ceram. Int. 39, 7 (2013) 7379.

[9] A.E. Galetti, M.F. Gomez, L.A. Arrúa, M.C. Abello, Appl. Catal. A 380, 1-2 (2010) 40.

[10] N. Vanderlaag, M. Snel, P. Magusin, G. Dewith, J. Eur. Ceram. Soc. 24, 8 (2004) 2417.
[11] F.M. Stringhini, E.L. Foletto, D. Sallet, D.A. Bertuol, O. Chiavone-Filho, C.A.O. Nascimento, J. Alloys Compd. 588 (2014) 305.

[12] X. Duan, D. Yuan, Z. Sun, C. Luan, D. Pan, D. Xu, M. Lv, J. Alloys Compd. 386, 1-2 (2005) 311.

[13] R. Ianoş, R. Băbuţă, C. Păcurariu, R. Lazău, R. Istratie, C. Butaciu, Ceram. Int. 43, 12 (2017) 8975.

[14] G.T. Anand, L.J. Kennedy, J.J. Vijaya, K. Kaviyarasan, M. Sukumar, Ceram. Int. 41, 1 (2015) 603.

[15] H.P. Macedo, R.L.B.A. Medeiros, A.L. Medeiros, Â.A.S. Oliveira, G.P. Figueredo, M.A.F. Melo, D.M.A. Melo, Mater. Res. 20 (2017) 29.

[16] K. Sakoda, M. Hirano, Ceram. Int. 40, 10 (2014) 15841.

[17] R.K. Sharma, R. Ghose, Ceram. Int. 40, 2 (2014) 3209.

[18] S.V. Motloung, F.B. Dejene, H.C. Swart, O.M. Ntwaeaborwa, Ceram. Int. 41, 5 (2015) 6776.

[19] L. Gama, M.A. Ribeiro, B.S. Barros, R.H.A. Kiminami, I.T. Weber, A.C.F.M. Costa, J. Alloys Compd. 483, 1-2 (2009) 453.

[20] M.A. Gabal, Y.M. Al Angari, A.Y. Obaid, A. Qusti, Adv. Powder Technol. 25, 1 (2014) 457.

[21] A.P.S. Peres, A.C. Lima, B.S. Barros, D.M.A. Melo, Mater. Lett. 89 (2012) 36.

[22] A.F. Costa, P.M. Pimentel, F.M. Aquino, D.M.A. Melo, M.A.F. Melo, I.M.G. Santos, Mater. Lett. 112 (2013) 58.

[23] G.P. Figueredo, A.F.M. Carvalho, R.L.B.A. Medeiros, F.M. Silva, H.P. Macêdo, M.A.F. Melo, D.M.A. Melo, Mater. Res. 20 (2017) 254.

[24] F.M. Aquino, D.M.A. Melo, P.M. Pimentel, R.M. Braga, M.A.F. Melo, A.E. Martinelli, A.F. Costa, Mater. Res. Bull. 47, 9 (2012) 2605.

[25] F.S. Oliveira, P.M. Pimentel, R.M.P.B. Oliveira, D.M.A. Melo, M.A.F. Melo, Mater. Lett. 64, 24 (2010) 2700.

[26] P.M. Pimentel, S.V.M. Lima, A.F. Costa, M.S.C. Câmara, J.D.C. Carregosa, R.M.P.B. Oliveira, Ceram. Int. 43, 8 (2017) 6592.

[27] A. Guo, M. Roso, M. Modesti, J. Liu, P. Colombo, J. Eur. Ceram. Soc. 34, 2 (2014) 549.

[28] G. Rani, Powder Technol. 312 (2017) 354.

[29] N. Li, Y. Cao, R. Zhao, Y. Xu, L. An, Sens. Actuators A 263 (2017) 174.

[30] M. Wilamowska, M. Graczyk-Zajac, R. Riedel, J. Power Sources 244 (2013) 80.

[31] J. Okal, M. Zawadzki, Appl. Catal. A 453 (2013) 349.

(Rec. 12/09/2018, Ac. 03/11/2018) 